\title{
Introduction
}

Asia, the continent just across the Pacific Ocean from the US, has been pushed into unchartered waters with the election of Donald Trump to the presidency of the US. The challenge of navigating this "new normal" comes just as Asia's own economies and politics are more vulnerable and fragile than they have been for a very long time.

How well prepared is Asia for this new phase in its renaissance following almost two centuries in an economic and political abyss? What are the major challenges that Asia faces? In short, what next for the Asian Century?

\section{US Reboots Post-War Asia}

In the aftermath of World War 2 and the Korean War, the US planted the seeds for an "Asian Century" being realized in the twenty-first century. It remade its arch-enemy Japan into a democracy with a pacifist constitution. It offered security alliances and partnerships to Japan, Korea, the Philippines, Taiwan, Thailand and Singapore. It provided financial assistance to rebuild war-torn economies. America's open markets enabled these countries to pursue export-driven development. And the post-war liberal international order led by the US, which includes the United Nations, the International Monetary Fund (IMF), the World Bank and

The original version of this chapter was revised. An erratum to this chapter can be found at https://doi.org/10.1007/978-981-10-7182-9_12

(C) The Author(s) 2018

J. West, Asian Century... on a Knife-edge, https://doi.org/10.1007/978-981-10-7182-9_1 
the World Trade Organization (WTO), formerly the General Agreement on Tariffs and Trade, underpinned an open and secure international system which facilitated Asia's development.

To be sure, sound domestic policies and strong leadership in many Asian countries played an important role. But the contribution of the US was crucial.

There were of course periods of tension. By the 1970s and 1980s, the US and other Western countries pushed Japan to open its highly protected markets and to invest in their own economies. It was time for Asia's export giant to allow more imports. And the US even felt under threat as Japan seemed to be taking over its mantle as the world's leading economy. This apparent threat faded from view with Japan's subsequent financial crisis in the 1990s.

When China began opening its economy from 1978, the US was also there to welcome Chinese exports, students, migrants and more recently Chinese investors. China's economy would experience a dramatic wave of economic growth following its membership of the WTO in 2001, which was supported by the US Clinton administration and business community. True, the US and other Western countries benefited handsomely from growing economic linkages with China and other Asian countries, even if they have been partly responsible for widening income inequality. And it has been hoped that closer economic relations would promote peace and security through the mutual interdependence that they create.

\section{From Asian Renaissance to Asian Century Hype}

Speculation that the twenty-first century could belong to Asia reached a crescendo around the period 2010-2012. The US had been flattened by its Wall Street crisis. Europe was knocked out by its sovereign debt crisis and the side effects of America's financial crisis.

At the same time, China became the growth center for the world economy, thanks to a mega stimulus package from the Chinese government. This boosted economic growth worldwide, especially for China's Asian trading partners and for commodity exporters like Australia, Brazil and Indonesia, along with many African and other Latin American countries.

Many saw an Asian Century as a foregone conclusion. Certainly, the Chinese leadership adopted an air of triumphalism, and a period of assertive Chinese foreign policy began with the main targets being Japan and the US.

Singaporean intellectual Kishore Mahbubani set the tone for Asian Century "hype" when he announced that "the last two centuries of Western domination of world history have been a major historical aberration. From 
the years 1 to 1820 , the two largest economies of the world were those of China and India ... All historical aberrations come to a natural end. Therefore the Asian Century is irresistible and unstoppable."

Some of the many signposts of Asian Century hype were:

- US President Barack Obama's comments in 2011 when he announced his administration's "pivot" (or "rebalance") to Asia-"As the world's fastest growing region-and home to more than half the global economy-the Asia Pacific is critical to achieving my highest priority, and that's creating jobs and opportunity for the American people ... as a Pacific nation, the United States will play a larger and long term role in shaping this region and its future."2

- Australian Prime Minister Julia Gillard's declaration at the launch of her government's 2012 White Paper on the Asian Century"Whatever this century brings, it will bring Asia's return to global leadership, Asia's rise. This is not only unstoppable, it is gathering pace ... Asia will become home to most of the world's middle class by as early as 2025 . Not only becoming the world's largest producer of goods and services; becoming the world's largest consumer of them." 3

- After being blackballed by China for meeting with the Dalai Lama in 2012, British Prime Minister David Cameron committed one of the biggest kowtows in modern history, when he announced in 2015 that the UK would join the China-led Asian Infrastructure Investment Bank, in defiance of the wishes of the US. White House spokesmen could only bemoan the UK's "constant accommodation" of the Chinese government. Around the same time, Cameron declared that the UK is "China's best partner in the West", while at the same time it had seemingly abandoned its responsibilities to Hong Kong, its former colony, which is suffering from Beijing's abuses of the "One Country, Two Systems" regime.

- Chinese President Xi Jinping's press article, on the occasion of a 2014 visit to India, in which he wrote- "I am confident that as long as China and India work together, the Asian century of prosperity and renewal will surely arrive at an early date."4

- A 2006 speech by Indian Prime Minister, Manmohan Singh, in which he said- "The most important development, I believe, of the twenty-first century will be the rise of Asia. China has already trebled its share of world GDP over the past two decades and India has 
doubled it. Both these giant economies of Asia are bound to gain a considerable part of their share of world GDP that they had lost during the two centuries of European colonialism." 5

- In 2011, the Asian Development Bank projected, under an "Asian Century" scenario, that Asia could account for over half the world economy by 2050 , and an additional 3 billion Asians could enjoy living standards similar to those in Europe today. ${ }^{6}$

\section{From Asian Century Hype to Donald J. Trump}

As with most bubbles of hype, things have since come back down to earth, and the mood has fundamentally changed. The US economy has rebounded and become the strongest point of a weak global economy. China is struggling under the weight of its massive debt, large capital outflows, rapidly aging population and other challenges. And many other Asian countries have lost their economic mojo, in no small part due to the slowdown of world trade and concerns about "deglobalization". In other words, the likelihood that the twenty-first century might belong to Asia has greatly diminished.

Despite the return to economic growth, full employment and financial stability under the Obama presidency, a wave of popular discontent saw the election of Donald Trump to the US presidency, rather than Hillary Clinton, Obama's anointed successor. While there were many factors behind Trump's success, his anti-Asia and especially anti-China rhetoric was a key element of his "Make America Great Again" mantra.

Indeed, during the election campaign and before his inauguration, Donald Trump had much to say about Asia. He accused China of raping the US. He threatened to label China a currency manipulator, to levy an import tariff of $45 \%$ on American imports from China, to implement a "border-adjustment tax" on all imports and to penalize companies that locate manufacturing investments in China rather than the US. He called the Trans-Pacific Partnership (TPP) a "disaster" and a "rape" of the American people.

Trump criticized China for its island-building program and militarization in the South China Sea, and for not helping control North Korea. He argued that "the concept of global warming was created by and for the Chinese in order to make U.S. manufacturing non-competitive." $\mathrm{He}$ threatened to withdraw the US from the Paris Climate Change Agreement, which was forged through US-China leadership. Trump also threatened 
to make Japan and Korea pay more for the US military troops and assets that are defending them and suggested that they could acquire nuclear weapons. Trump also questioned the "One-China Policy" and spoke by telephone with Taiwan President Tsai Ing-wen.

\section{Trump Administration Moves into Action}

The Trump administration moved quickly into action on the Asian front. To the dismay of the US business community, Trump withdrew the US from the TPP. This was after all a trade agreement designed by US business, for the benefit of US business, pushed onto allies and partners, and then rejected by a businessman president. Above all, the TPP was a manifestation of US leadership to establish modern rules of the game for trade and investment in the Asia Pacific. China was not a signatory, as it could never have signed up for the agreement's conditions for state-owned enterprises, intellectual property and labor rights. (Under Japanese leadership, the remaining 11 TPP signatories are discussing the possibility of pursuing with the TPP without the US.)

Trump's rhetoric on trade policy has been evolving and softening from the defiant protectionist messages during the election campaign and in his inaugural speech. Trump is now emphasizing his support for both free and fair trade. According to the president's 2017 Trade Policy Agenda, ${ }^{7}$ America has not benefited from its trade deals over the past couple of decades due to the lack of reciprocity in trading relations. Trump would now like US trade policy to focus on bilateral, rather than multilateral, deals, to secure better market access. He plainly has China, Japan and Korea in his sights.

While the US Treasury has backed off from Trump's claims of Chinese currency manipulation, it has established a "Monitoring List" of major trading partners that merit close attention to their currency practices, which includes four Asian economies, namely China, Japan, Korea and Taiwan. ${ }^{8}$ Despite some softening in Trump's trade rhetoric, there remains a strongly protectionist undercurrent, as Trump's overriding trade policy goals are reducing the US' bilateral trade deficits (notably with China, Japan and Korea) and bringing manufacturing jobs back to America. Trump has also threatened to disregard WTO dispute settlement rulings. While Trump is promising to shake up trade relations with Asia, China is actively seeking to foster trade within Eurasia through its Belt and Road Initiative. 
Trump had a successful first summit with Chinese President Xi Jinping in April 2017 and seemed to have enlisted his support to help control North Korea. However, it only took a couple of months for Trump to realize that China is reluctant to seriously tackle North Korea for fear of destabilizing the regime. The Xi-Trump honeymoon was then over, as quickly as it started, when the Trump administration announced sanctions on Chinese entities for their dealings with North Korea, also announced actions against China's alleged dumping of steel exports, gave a green light for a \$1 billion arms sale to Taiwan and sailed a US destroyer through the Chinese-occupied South China Sea. And Trump's launching in August 2017 of an investigation into China's alleged theft of US intellectual property has deeply troubled the Chinese government and raised the specter of a possible trade war between China and the US.

To the great disappointment of China and the rest of the international community, President Trump has also withdrawn the US from the Paris Climate Change Agreement and rolled back Obama-era clean energy regulations. China and the European Union are now positioning themselves as global leaders in the fight against climate change, despite China's appalling domestic environment and the bad environmental performance of Chinese investors in Africa and Latin America.

Trump officials reaffirmed the US commitment to its alliances with Japan and Korea, while Trump himself indicated his support for the "One-China Policy" in a telephone conversation with Chinese President $\mathrm{Xi}$ Jinping. This is seen to have been a big back down for Trump, as $\mathrm{Xi}$ reportedly refused to talk with him until Trump honored the One-China Policy.

It also seems that Donald Trump's administration is planning to defy Winston Churchill's advice that "to jaw-jaw is always better than to warwar". His 2017 budget proposal involves increasing funding to the US military by $9 \%$, while cutting the State Department's diplomacy and foreign aid by a combined 28\%, and also the Environment Protection Agency by $31 \%$. "There is no question that this is a hard-power budget; it is not a soft-power budget," said Mick Mulvaney, the director of the Office of Management and Budget. While the US Congress is seeking to restore funding for these agencies, Trump's budget proposals certainly set the tone for his administration's approach to international relations.

Trump's hard-power approach to international relations was soon evident in its approach to North Korea. Administration leaders were quick to dismiss the Obama administration's "strategic patience" approach and 
announce that all options, including military options, were now on the table. Various administration comments have gyrated between advocating military intervention and regime change, and dialogue and diplomacy. It is hardly surprising that the paranoid North Korean regime, which is convinced that the US wants to remove it, should accelerate its missile and nuclear weapon development. As Trump's foreign policy becomes mired in a series of mixed messages, and the administration becomes increasingly chaotic in Washington, China appears a much steadier hand on the international stage.

Overall, Asia is now faced with a likely deterioration in key factors that have driven its development-an open US market, a relatively benign security environment and a stable global economic system. It is not surprising that the US credibility and standing in the region are now taking a beating. For example, in an interview before the US elections, Singapore's Prime Minister Lee Hsien Loong said that a failure to ratify the TPP "would be a very big setback for America." Former Washington Post reporter, Paul Blustein, has remarked that "this administration has no respect for international institutions." And Australia's former foreign minister Gareth Evans has said that Donald Trump is "manifestly the most ill-informed, under-prepared, ethically challenged and psychologically illequipped president in US history" and that Australia should reduce its dependence on the US alliance and accept China as a legitimate "global rule maker".

This sea change across the Pacific is colliding with a raft of major challenges, as virtually all Asian countries have moved into middle-income status. The evidence shows that graduation from low-income to middleincome status can be relatively easy. By getting just a few things right, countries can achieve rapid economic growth, as even Bangladesh has shown. But transitioning through the middle-income group and graduating to high-income status requires a vastly more sophisticated set of policies and dealing with a complex range of challenges, notably the seven highlighted in this book. Countries can fall into a "middle-income trap", meaning that they are unlikely to graduate from middle-income to highincome status, unless they tackle such challenges.

The arrival of "Trumpism" only highlights the need for a dispassionate and realistic assessment of where we are in terms of realizing an Asian Century and what are the main challenges facing Asian economies if they are to realize their immense potential. This is the mission of this book. In the first section, we take stock of Asia's economic and social development. 
In the following section, we analyze seven challenges for an Asian Century, before speculating about what's next for the Asian Century.

\section{TAking Stock of Asia’s Economic And Social DeVELOPMENT}

Most Asian countries have achieved stunning economic growth over the past half century or more, starting with Japan, followed by the four Asian tigers of Hong Kong, Korea, Singapore and Taiwan, and then the Southeast Asian economies of Indonesia, Malaysia and Thailand, and China, India and Vietnam. But despite the hype of Asia's economic miracle, the harsh reality of our assessment in Chap. 1 is that Asia is suffering from stunted economic development. No major Asian economy has caught up with global leaders like the US and Germany in terms of GDP per capita and living standards, and there is little likelihood of such catchup occurring over the foreseeable future. The city-states of Hong Kong and Singapore stand out for having the highest GDP per capita in Asia. But when they are compared with cities like London, New York or Zurich, their performance is much less remarkable.

What is the cause of Asia's stunted development? What is holding it back? While Asia's dynamic economies are a diverse bunch, they are all similar in the sense that, apart from Hong Kong and Singapore, none of them could be considered open market economies. The heavy hands of government and business elites played an important role in their economic development, but all too often they are now the main factor holding them back today. There are many other more specific challenges facing Asia, seven of which are examined in Chaps. 4, 5, 6, 7, 8, 9 and 10.

Size does matter, however. And countries like China, India and Indonesia, thanks in large part to their enormous populations, have some of the world's biggest economies. Today, China has the world's biggest economy in purchasing power parity terms, ahead of the second-placed US and third-placed India. Japan is the fourth placed, while Indonesia is eighth, just ahead of the UK and France. China, India and Indonesia have been able to transform economic weight into economic, political and military power, even though their GDP per capita, and their levels of economic, business and technological sophistication are modest (China's GDP per capita is only one quarter of that of the US). Without further economic, social and political development, these countries will remain 
fragile superpowers. It is no coincidence that China's increasing repression at home, and aggressive attitude toward its neighbors, has come at a time of fragility in its domestic economy.

The importance of size among Asian economies will be highlighted during the second half of this century, when India's total GDP could overtake China's. Factors driving this transition will be population, with India's projected to be some $50 \%$ higher than China's by 2100 , and economic growth, if India can maintain its edge on China thanks to more ambitious reforms. Needless to say, such a transition could have great geopolitical implications in Asia.

The hype about Asia's dramatic economic rise has only been matched by similar hype about the emergence of Asia's middle class. And while it is true that Asian lives have improved immeasurably in tandem with economic development, only a small share of Asian citizens could be described as middle class, and the middle class is receding in Japan and Korea along with rising inequality and poverty. Today, half of Asia's population is stranded between poverty and the middle class, living in a zone of vulnerability and precarity, based on their income and consumption possibilities. And there are factors other than raw money which are also holding Asians back from joining the middle class, as we examine in Chap. 2: the vulnerability and precarity of informal/non-regular employment; deprivations like the lack of clean drinking water, inadequate health facilities and sanitation (i.e., clean, safe and hygienic toilets); the impact of Asia's all-too-frequent natural disasters; poor access to education and the Internet; and above all, Asia's appalling human rights.

The realization of a middle-class Asia would be a commendable achievement. But while economic growth may have been the most important driver of better Asian lives, the future will require a more active contribution of government, which has not been very effective in providing their citizens with the basic social services, rights and freedoms. And given the flawed politics of most Asian countries, civil society and trade unions will need to become much more assertive to ensure that governments are working for all citizens, not just entrenched elites.

\section{Seven Challenges for an Asian Century}

Asia faces an enormous array of challenges in its quest to catch up to world leaders in terms of GDP per capita, and economic, business and technological sophistication, and in creating true middle-class societies for its 
citizens. In Chaps. 4, 5, 6, 7, 8, 9 and 10, we examine seven of these challenges.

Global value chains (GVCs) have provided Asia's emerging economies with a fast track to development, as we discuss in Chap. 4. Perhaps the most well-known GVC is that of Apple's iPhone which is designed, marketed and branded in California, uses high-tech components from Japan, Korea, Taiwan and elsewhere, and is assembled in China by Foxconn, Taiwanese company. But despite the immense benefits of participating in GVCs, most Asian countries are still capturing very little value from GVCs. Much greater efforts are required to get better value by opening markets, and strengthening human capital, and technological and innovative capacities. President Trump's decision to withdraw the US from the TPP, his rejection of multilateral trade and investment deals, and his protectionism will undermine the further development of Asia's GVCs. There is no sign that any Chinese efforts, such as through the Regional Comprehensive Economic Partnership, would be an effective replacement for the TPP. Labor rights abuses have also been frequent in many GVCs. Asian governments need to more actively promote socially responsible GVCs in order to foster decent middle-class societies.

The movement of Asians from the countryside to towns and cities (urbanization), and from low-productivity jobs in the rural sector to higher-productivity jobs in factories for GVCs and the urban service sector, has also been a key driver of Asia's economic development, as we examine in Chap. 5. But Asia's model of urbanization is flawed in many respects. In China, migrants from rural areas are denied access to social services. In all emerging Asian economies, too many people leave rural poverty only to live in urban slums with poor infrastructure, while most of Asia's cities are environmental disasters. President Trump's withdrawal of the US from the Paris Climate Change Agreement will only exacerbate the vulnerability of Asian cities to the impact of global warming. In the case of Asia's advanced countries, very few cities offer an "ecosystem" which fosters innovation-driven development. Asian governments face a raft of challenges to make the most of urbanization's immense potential.

Economies and societies will realize their full potential only when all citizens are given a chance to participate. But discrimination, prejudice and persecution are rife in Asia, as our review shows in Chap. 6 which highlights the cases of: the LGBT community; Japanese women; South Asian women who suffer gendercide, forced child marriages and honor killing; Asia's indigenous peoples like West Papuans, Tibetans and China's Uighurs; 
Sri Lanka's Tamil community; and India's lower castes. President Trump's proposed slashing of the budgets of the State Department and USAID will likely affect the US leadership in the promotion of the rights of the LGBT community, women and other minority rights in Asia and elsewhere.

Most Asian countries face intractable demographic dilemmas, as we analyze in Chap. 7. In much of East Asia, fertility has plummeted below replacement rates, populations are aging, workforces declining, and in Japan the population has begun falling. And yet governments are slow to react. At the same time, in South Asia, Indonesia and the Philippines, a youth bulge is bursting into the workforce, but much of this youth is not well educated and there are not enough jobs on offer. A potential demographic dividend could easily morph into an explosion of social frustration. Connecting these two demographic realities is the potential for mutually beneficial migration, and yet ethnocentric Asia is barely open to migration. Asia's skilled emigrants go to Australia, Canada, New Zealand and the US, while many of Asia's lower skilled migrants go off to the Middle East to suffer. Countries like China, India and the Philippines which rely heavily on migrants' remittances could suffer from President Trump's tightening of migration policies. These three countries account for almost all of America's 1.5 million illegal migrants coming from Asia, and $13 \%$ of all illegal migrants. And India has been the main beneficiary of the US Hl-B temporary visa program.

Asia is crying out for democracy and better governance to improve the foundations for stronger economies and decent middle-class societies. And yet, according to some measures, there would not be even one mature democracy in Asia, as we explore in Chap. 8. Contrary to the hopes of political scientists, economic development has fostered too few democracies in Asia. Asia's political landscape is deeply flawed with: oligarchic democracies in Japan and Korea; pro-business soft dictatorships in Hong Kong, Malaysia and Singapore; Chinese client states in Cambodia and Laos; weak and fragile democracies in India, Indonesia, the Philippines, Mongolia, Sri Lanka, Bangladesh and Nepal; military-dominated governments in Thailand, Pakistan and Myanmar; and staunchly authoritarian states in China, North Korea and Vietnam. Asia will never have decent middle-class societies and innovative economies while repression, propaganda, censorship and human rights abuses occur in too many of its countries. And President Trump is not helping as he cozies up to some of Asia's authoritarian leaders, and has made it clear that promotion of democracy and human rights is not a priority of his administration. 
One of the many consequences of these flawed politics is that, as Asia has moved toward the center of the global economy, it has also moved to the center of the global criminal economy, as we examine in Chap. 9. Asia is a major player in many aspects of economic crime like counterfeiting and piracy, illegal drug production and trafficking, environmental crimes, human trafficking and smuggling, corruption and money laundering, and cybercrime. And while flawed politics is one of the causes, this criminality is eating away at the integrity of the state, as state actors are very often criminals themselves or are colluding with criminals.

While many factors have underpinned Asia's renaissance over the past half century or more, the relative peace that the region has enjoyed has been perhaps the most important. And cooperation between Asian countries has also made a positive contribution, especially through the Association of Southeast Nations (ASEAN), which has become a fulcrum for broader Asian cooperation. Looking ahead, as we analyze in Chap. 10, the ability of Asia to continue to live together in peace and harmony will perhaps be the most important determinant of a successful Asian Century.

But today, the relative stability of post-war Asia, led by the US, is being shaken by the rise of China, as China is now engaged in a bitter power struggle with the US and its Asian allies for the political leadership of Asia. There is much debate about whether this will lead to military conflict between China and the US. In any event, the US seems to be losing its hold over Asia, something which will likely accelerate under the Trump administration. This means that it will become ever more necessary for Asian countries to cooperate better together. But this will be a great challenge in light of the tensions involving China, North Korea, Japan, Taiwan, Hong Kong, South Korea and India.

\section{What Next for the Asian Century?}

The prospects for Asia overcoming stunted economic and social development, and realizing an Asian Century with advanced economies and middle-class societies, depend on how Asia responds to the seven challenges identified in this book. Unfortunately, there is too little evidence of Asia's major countries seizing the moment. Indeed, the cases of Japan, and more recently Korea and China, are salutary, where governments have avoided and postponed difficult reforms.

Trump's America will also shape the contours of a possible Asian Century. As argued, we will likely see a deterioration in key factors that 
have driven Asia development - an open US market, a relatively benign security environment and a stable global economic system. This is a tragedy for Asia, as China, the US' competitor, is not a promoter of open markets, good governance and the international rule of law.

Many observers speculate that Trump will not survive a year or two or beyond his first term. This is far from certain. His rise to the presidency was equally improbable. Even post-Trump, we should not assume a return to the US as a promoter of open markets and globalization, and a friend of democratic partners and the liberal international system. America has been struck by a wave of populism, and in particular nationalism (make America great again), nativism (secure our borders) and protectionism (protect American workers), ${ }^{10}$ which is unlikely to go away anytime soon.

But if Asia continues to muddle through, in some decades time, the region could account for over half the world economy, far outstripping the West in total economic size. In these circumstances, no major Asian economy would have approached world leaders like the US and Germany in terms of GDP per capita, or economic, business and technological sophistication. Moreover, Asia could remain a democratic desert, with not one full democracy, and with continuing widespread human rights abuses and restrictions on personal freedoms. In other words, Asia would have the world's greatest economic weight, and be a leading economic and political power, but would remain a pygmy in terms of economic, social and political development. Asia's main power comes from its enormous population, currently about $55 \%$ of the world's total, compared with only $18 \%$ for the West.

Needless to say, the incongruities of such a scenario could generate even greater geopolitical tensions than we see today.

These incongruities would test the capacity of the international community to cooperate on issues like open trade and investment, democracy and human rights, the global environment, protection of intellectual property rights, economic crime, international rule of law, law of the sea and natural disasters. Why? Because forging consensus and working together requires shared interest and values, and a culture of cooperation and trust.

Beyond these incongruities, there are endless possibilities of economic, social, political and military crises in Asia-mostly due to the likely failure to deal with our seven challenges for an Asian Century.

Economic crisis is stalking several Asian countries, most notably Japan and China with their massive debt problems. And anti-globalization populism 
could break one of the most important drivers of Asia's rapid development, namely open trade and investment. Social crisis could be on the cards for India, Indonesia and the Philippines with their bulging youth populations, if they are unable to find decent jobs. Multi-ethnic countries like India and Indonesia could easily descend into violence as groups suffering from discrimination, prejudice and persecution mobilize themselves against dominant elites. And as natural disasters and environmental problems increasingly hit Asia's overcrowded and badly planned cities, social crises will also accelerate.

Continued authoritarian politics and social repression in China, North Korea and Vietnam could provoke political crises as citizens demand cleaner government and democratic government. Social unrest is already rampant in China, and North Korea has thousands of regime opponents locked away in secret gulags. The corruption crisis that engulfed the South Korean President Park Geun-hye and Samsung shows how fragile even Asia's most advanced countries can be.

The future of peace in Asia could be threatened by the great power struggle between China and the US. The US and China are unlikely to engage in a traditional military conflict, although the naval collisions involving the US Navy in 2017 show how easily accidents can occur, and possibly spiral out of control. They seem destined to remain "frenemies", that is both friends and rivals, with conflicts taking place in the areas of trade, intellectual property, international rule of law and cyber, rather than on the battlefield.

As China progressively displaces the US as Asia's hegemon, it will become ever more necessary for Asian countries to cooperate better together. In a region which is bristling with tensions involving China, North Korea, South Korea, Japan, Taiwan, Hong Kong, the South China Sea, ASEAN and India, this will be a great challenge. And while China's rise has been shaking Asia, the prospect of India's economy overtaking China's in the second half of the twenty-first century will require further adjustments by all. Any conflicts between Asian countries could do much to derail the prospects for an Asian Century. And the great risk for the US is being dragged into these conflicts between Asian countries, more than a straight head-on conflict with China.

Today, Asia is sitting on a knife edge. The potential of the region to generate good and happy lives for its citizens is enormous. But the requirements of success and the risks of failure are equally enormous. We cannot be sure of "what's next for the Asian Century". Indeed, anything could happen, and complacency of Asia's elites could be the Asian Century's greatest enemy. 


\section{Notes}

1. Schibotto, Emanuele, and Gabriele Giovannini (2015). Singapore's Role in the Asian Century-interview with Kishore Mahbubani. Asian Century Institute, 12 February 2015.

2. Obama, Barack (2011). Remarks by President Obama to the Australian Parliament, 17 November 2011.

3. Gillard, Julia (2012). Prime Minister's Speech at the launch of the White Paper on Australia in the Asian Century. Lowy Institute, 28 October 2012.

4. Xi, Jinping (2014). Towards an Asian Century of Prosperity. The Hindu, 17 September 2014.

5. Manmohan Singh, "Remarks at the LSE Asia Forum", (New Delhi, 7 December 2006).

6. Asian Development Bank (2011). Asia 2050: Realising the Asian Century.

7. The Office of the United States Trade Representative. President Trump's 2017 Trade Policy Agenda.

8. US Treasury, Treasury Releases Report on Foreign Exchange Policies of Major Trading Partners of the United States, 14 April 2017.

9. Lowy Institute. Conference on "Two decades after the Asian Financial Crisis: Have the world's financial firefighters learned anything?" Paul Blustein, former Washington Post reporter and Senior Fellow at the Centre for International Governance Innovation, 4 July 2017.

10. McGann, James G. 2016 Global Go to Think Tank Index Report.

Open Access This chapter is licensed under the terms of the Creative Commons Attribution 4.0 International License (http://creativecommons.org/licenses/ by $/ 4.0 /$ ), which permits use, sharing, adaptation, distribution, and reproduction in any medium or format, as long as you give appropriate credit to the original author(s) and the source, provide a link to the Creative Commons license and indicate if changes were made.

The images or other third party material in this chapter are included in the chapter's Creative Commons license, unless indicated otherwise in a credit line to the material. If material is not included in the chapter's Creative Commons license and your intended use is not permitted by statutory regulation or exceeds the permitted use, you will need to obtain permission directly from the copyright holder.

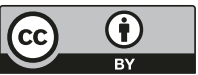

